\title{
Rare cause of arterial hypertension
}

\author{
Carina Arantes, ${ }^{1}$ Nuno Ferreira, ${ }^{2}$ Marta Ponte, ${ }^{2}$ Conceição Fonseca ${ }^{2}$
}

${ }^{1}$ Department of Cardiology, Hospital de Braga, Braga, Braga, Portugal

${ }^{2}$ Department of Cardiology, Centro Hospitalar de Vila Nova de Gaia Espinho, Vila Nova de Gaia, Porto, Portugal

\section{Correspondence to}

Dr Carina Arantes,

arantescarina@gmail.com

Accepted 8 November 2016

\section{DESCRIPTION}

We report the case of a man aged 55 years who was referred to our department for investigation of arterial hypertension. He had only a previous diagnosis of situs inversus. At presentation, his blood pressure was $190 / 100 \mathrm{~mm} \mathrm{Hg}$ in both arms, but significantly lower in lower limbs. The pulses were

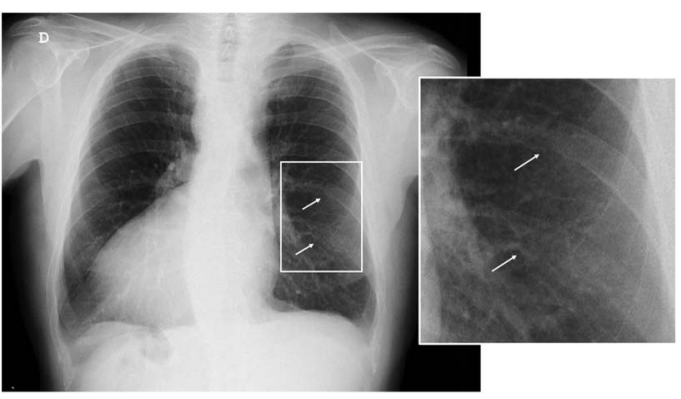

Figure 1 Chest radiogram showing bilateral rib notching (arrow). equal over both upper extremities, but lower limbs pulses were also weakly palpable. On cardiac auscultation, a grade II/VI systolic murmur was heard on the right scapular region.

Chest radiography showed dextrocardia and bilateral rib notching (figure 1).

The transthoracic echocardiography showed mild concentric hypertrophy and mild dilation of the ascending thoracic aorta; due to a poor suprasternal view, the aortic arch could not be adequately assessed.

Multislice CT angiography revealed a complete interruption of the aortic arch distal to the origin of the right subclavian artery (figures 2 and 3 ) and showed prominent collateral circulation to the descending aorta, predominantly via the internal mammary and intercostal arteries (figures 3 and 4).

After adjustment of antihypertensive drugs, it was achieved good blood pressure control. The case was considered for surgical repair, but, in view of the absence of symptoms, well-controlled blood
To cite: Arantes $C$, Ferreira $\mathrm{N}$, Ponte $\mathrm{M}$, et al. BMJ Case Rep Published online: [please include Day Month Year] doi:10.1136/ bcr-2016-218075

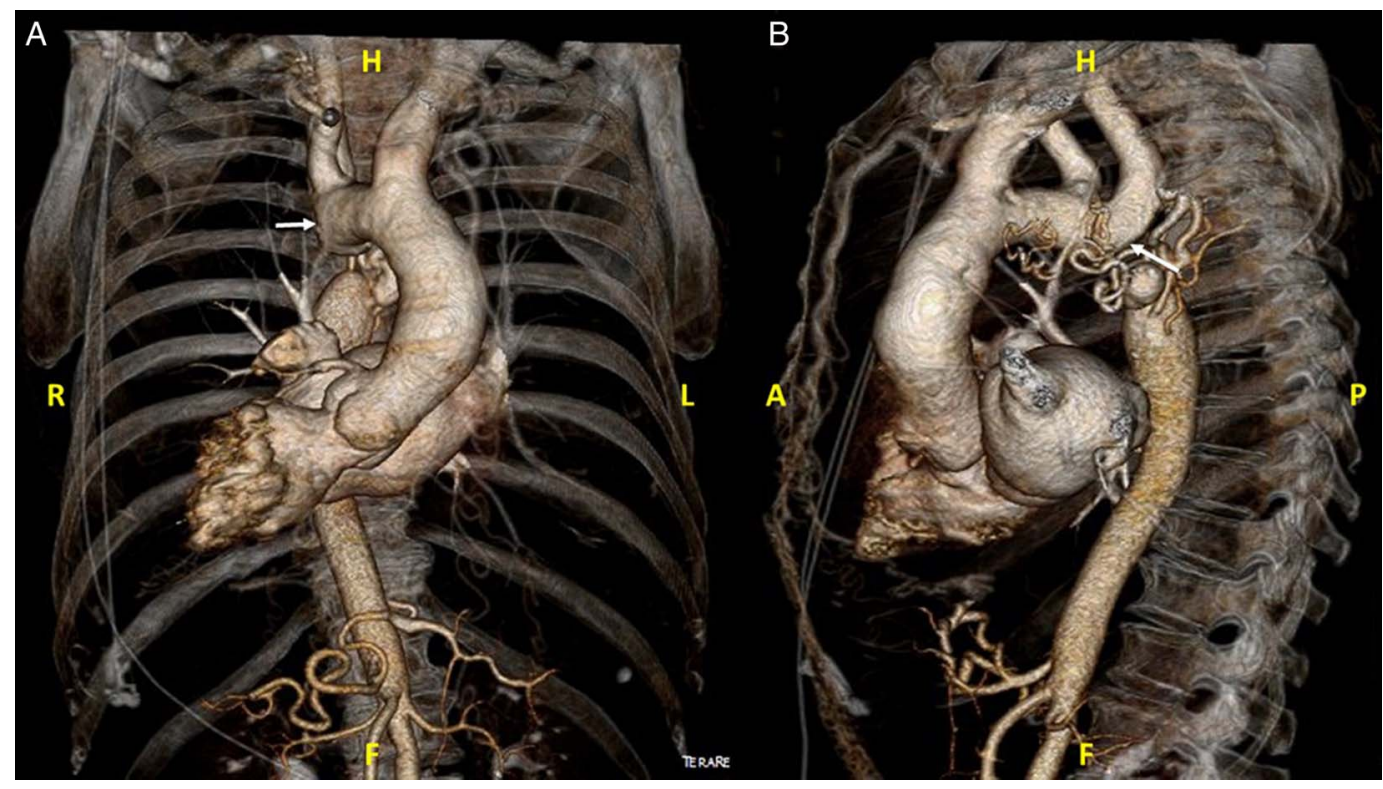

Figure 2 Three-dimensional CT angiography showing interrupted aortic arch (arrow) with complete discontinuity of the aortic lumen distal to the origin of the right subclavian artery. 


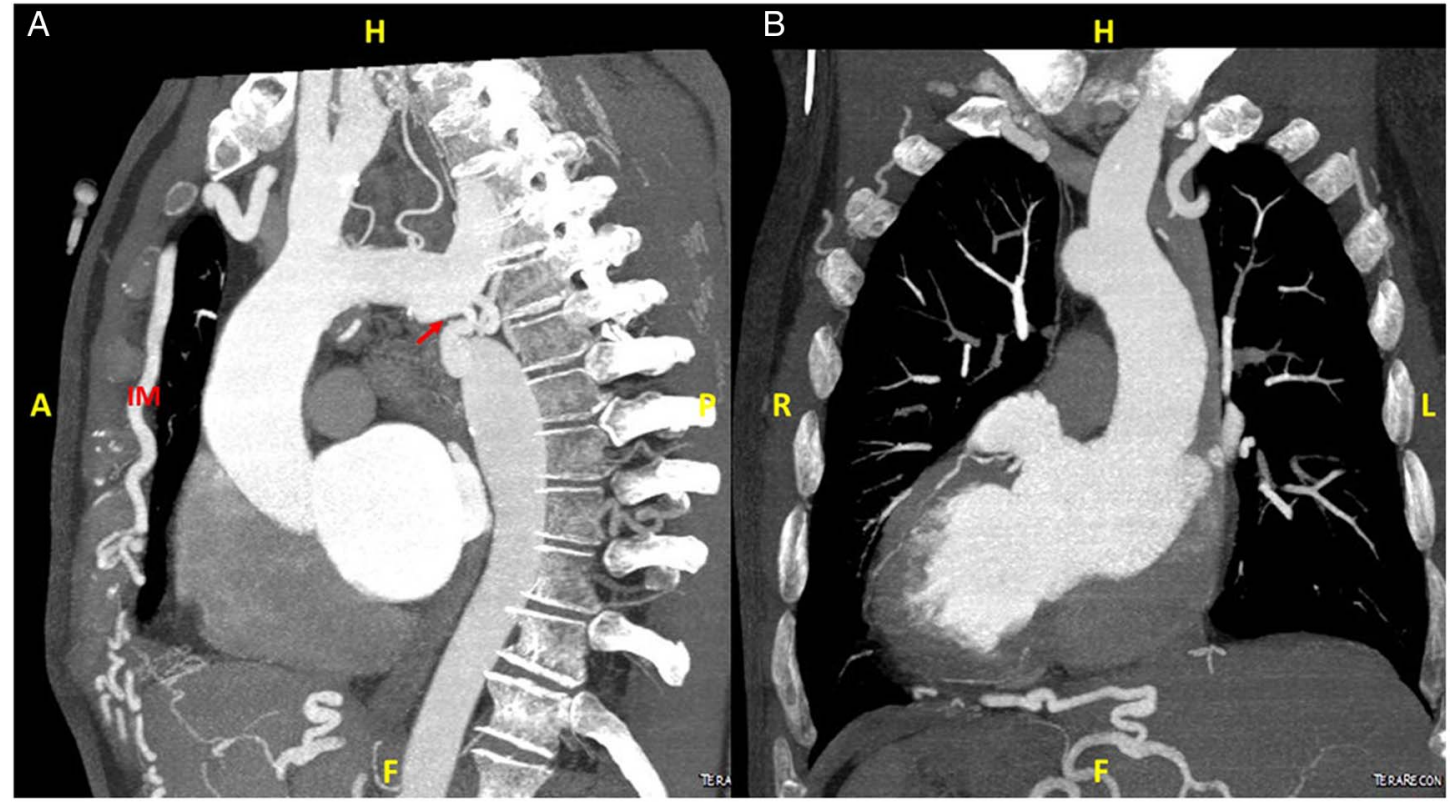

Figure $3 \mathrm{CT}$ angiogram showing a type A interrupted aortic arch with ectasia of internal mammary (intramuscular) artery.

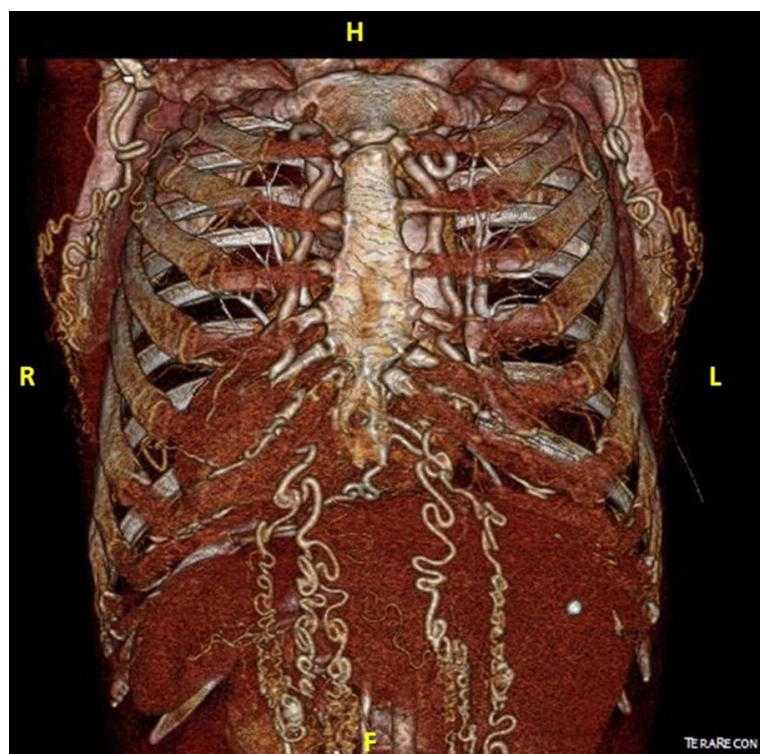

Figure 4 Three-dimensional CT angiography showing a collateral network ensuring circulation to the descending aorta.

pressure and extensive collateral vascularisation, a conservative therapy was chosen.

This case demonstrated the importance of a rigorous physical examination in the evaluation of this patient, which can allow the diagnosis of infrequent causes of secondary hypertension.

Contributors CA collected the data and wrote the manuscript. CF was the doctor responsible for the orientation of the case. NF reported CT angiography and reviewed the images for the article. MP and NF reviewed the manuscript for

\section{Learning points}

- Interrupted aortic arch (IAA) is defined as a complete loss of continuity between the ascending and descending aorta; it occurs in three per million live births, accounting for $1 \%$ of all congenital heart disease and it is commonly associated with other congenital anomalies. ${ }^{1}$

- This congenital anomaly is typically diagnosed during the neonatal period and if untreated the mortality is high, so this is a rare diagnosis in adulthood. The development of an extensive collateral network allows survival to adulthood. ${ }^{2}$

- A careful physical examination with lower blood pressure or weak pulses in lower limbs should raise suspicion of IAA or aortic coarctation, being the diagnosis confirmed by an imaging method. $^{3}$

important intellectual content. All the authors were involved in this clinical case and contributed to the conception of the work and gave final approval of this article.

Competing interests None declared.

Patient consent Obtained.

Provenance and peer review Not commissioned; externally peer reviewed.

\section{REFERENCES}

1 Erden I, Kayapinar O, Erden EC, et al. Silent interrupted aortic arch in an elderly patient. Cardiol I 2011;18:695-7.

2 Borgohain S, Gupta A, Grover V, et al. Isolated interrupted aortic arch in an 18-year-old man. Tex Heart Inst J 2013;40:79-81.

3 Ponte M, Ferreira A, Ferreira N, et al. Interrupted aortic arch: a misdiagnosed cause of hypertension. Rev Port Cardiol 2014;33:389.e1-e5. 
Copyright 2016 BMJ Publishing Group. All rights reserved. For permission to reuse any of this content visit http://group.bmj.com/group/rights-licensing/permissions.

BMJ Case Report Fellows may re-use this article for personal use and teaching without any further permission.

Become a Fellow of BMJ Case Reports today and you can:

- Submit as many cases as you like

- Enjoy fast sympathetic peer review and rapid publication of accepted articles

- Access all the published articles

- Re-use any of the published material for personal use and teaching without further permission

For information on Institutional Fellowships contact consortiasales@bmjgroup.com

Visit casereports.bmj.com for more articles like this and to become a Fellow 